\title{
Role of the general base Glu268 in nitroglycerin bioactivation and mechanism-based superoxide formation by aldehyde dehydrogenase-2
}

\author{
M Verena Wenzl*1, Matteo Beretta1 ${ }^{1}$, Antonius CF Gorren ${ }^{1}$, Pravas K Baral ${ }^{2}$, \\ Karl Gruber ${ }^{2}$, Michael Russwurm ${ }^{3}$, Doris Koesling ${ }^{3}$, Kurt Schmidt ${ }^{1}$ and \\ Bernd Mayer ${ }^{1}$
}

Address: ${ }^{1}$ Department of Pharmacology and Toxicology, Karl-Franzens-Universität Graz, A-8010 Graz, Austria, ${ }^{2}$ Department of Molecular Biosciences, Karl-Franzens-Universität Graz, A-8010 Graz, Austria and ${ }^{3}$ Department of Pharmacology and Toxicology, Ruhr-Universität Bochum, D-44780 Bochum, Germany

Email: M Verena Wenzl* - michaelaverena.wenzl@uni-graz.at

* Corresponding author

from 4th International Conference of cGMP Generators, Effectors and Therapeutic Implications

Regensburg, Germany. 19-21 June 2009

Published: II August 2009

BMC Pharmacology 2009, 9(Suppl I):P72 doi:I0.|I86/|47|-22 I0-9-SI-P72

This abstract is available from: http://www.biomedcentral.com/I47I-22/0/9/SI/P72

(C) 2009 Wenzl et al; licensee BioMed Central Ltd.

\section{Background}

Mitochondrial aldehyde dehydrogenase (ALDH2) plays an essential role in nitroglycerin (GTN) bioactivation, resulting in formation of nitric oxide (NO) or a related activator of soluble guanylate cyclase (sGC) and consequently in cGMP-mediated vasorelaxation [1]. ALDH2 denitrates GTN to 1,2-glyceryl dinitrate (1,2-GDN) and nitrite but also catalyzes reduction of GTN to nitric oxide (NO) [2]. To elucidate the mechanism of ALDH2-catalyzed GTN bioactivation in relation to the established ALDH 2 activities (dehydrogenase, esterase), we compared the function of the wildtype (WT) enzyme with a mutant lacking the general base Glu268 (E268Q).

\section{Results}

Despite low dehydrogenase and esterase activities ( $<3 \%$ of WT) the E268Q mutant exhibited virtually unaffected rates of GTN denitration $(133 \pm 11 \%$ of WT). The nucleotide cofactor NAD caused a pronounced increase in the rates of 1,2-GDN formation by WT-ALDH2 from $1.21 \pm$ 0.18 to $8.73 \pm 0.09 \mathrm{nmol} \times \mathrm{min}^{-1} \times \mathrm{mg}^{-1}$, but inhibited the reaction catalyzed by the E268Q mutant to about 3\% of WT. In contrast to WT-ALDH2, the E268Q mutant generated detectable NO measured with a Clark-type electrode even in the absence of superoxide dismutase (SOD). The apparent initial rate was $2.1 \pm 0.31 \mathrm{nmol} \times \mathrm{min}^{-1} \times \mathrm{mg}^{-1}$ and the peak concentration of NO was $0.17 \pm 0.03 \mu \mathrm{M}$. Purified sGC was activated by GTN in the presence of increasing amounts of WT-ALDH2, but the effect reached a plateau of about $30 \%$ of maximal sGC activity at $50-100$ $\mu \mathrm{g}$ of ALDH2 $\left(9.0 \pm 0.38 \mu \mathrm{mol}\right.$ cGMP $\left.\times \mathrm{min}^{-1} \times \mathrm{mg}^{-1}\right)$. Superoxide dismutase markedly potentiated the effect of ALDH2, resulting in maximal sGC activation with $25 \mu \mathrm{g}$ of protein. With E268Q-ALDH2, maximal sGC activation was observed with $100 \mu \mathrm{g}$ of protein even in the absence of SOD. In the presence of SOD, the effect of the mutant was virtually identical to that of WT-ALDH2. Formation of superoxide was confirmed by determination of hydroethidine oxidation that was inhibited by SOD and the ALDH 2 inhibitor chloral hydrate. E268Q-ALDH2 exhibited about $50 \%$ lower rates of superoxide formation than the WT enzyme.

\section{Conclusion}

Our results suggest that E268 is involved in the structural organization of the NAD binding pocket but is not required for GTN denitration. Mechanism-based superoxide formation by ALDH2 may essentially account for oxi- 
dative stress in GTN-exposed blood vessels contributing to nitrate tolerance.

\section{Acknowledgements}

We thank Margit Rehn for excellent technical assistance. This work was funded by the Fonds zur Förderung der Wissenschaftlichen Forschung in Austria (W90I DK Molecular Enzymology and P20669) and the Deutsche Forschungsgemeinschaft (KOII57/4-I).

\section{References}

I. Chen Z, Foster MW, Zhang J, Mao L, Rockman HA, Kawamoto T, Kitagawa K, Nakayama KI, Hess DT, Stamler JS: An essential role for mitochondrial aldehyde dehydrogenase in nitroglycerin bioactivation. Proc Natl Acad Sci USA 2005, 102:12159-12164.

2. Beretta M, Gruber K, Kollau A, Russwurm M, Koesling D, Goessler W, Keung WM, Schmidt K, Mayer B: Bioactivation of nitroglycerin by purified mitochondrial and cytosolic aldehyde dehydrogenases. J Biol Chem 2008, 283: 17873-17880.

Publish with Bio Med Central and every scientist can read your work free of charge

"BioMed Central will be the most significant development for disseminating the results of biomedical research in our lifetime."

Sir Paul Nurse, Cancer Research UK

Your research papers will be:

- available free of charge to the entire biomedical community

- peer reviewed and published immediately upon acceptance

- cited in PubMed and archived on PubMed Central

- yours - you keep the copyright

Submit your manuscript here:

http://www.biomedcentral.com/info/publishing_adv.asp 